\title{
The Impact of Separate Taxation on the Intra-Household Allocation of Assets: Evidence from the UK
}

\author{
Melvin Stephens Jr. ${ }^{+}$ \\ Carnegie Mellon University and NBER \\ Jennifer Ward-Batts* \\ Claremont McKenna College
}

May 2003

\begin{abstract}
The income tax system in the United Kingdom moved from joint to independent taxation of husbands' and wives' income in 1990. One interesting aspect of independent taxation is the ability for households to choose the division of household assets between the two spouses. This tax reform therefore creates an opportunity for households to engage in a form of tax avoidance by shifting their investment income to the spouse with the lower marginal tax rate. We use Family Expenditure Survey data to examine the impact of this tax reform on the magnitude of investment income shifting between spouses with different marginal tax rates. We find a sizeable shift in the share and incidence of asset income claimed by wives, who typically have lower marginal tax rates, as well as in the incidence of the wife claiming all the household asset income, indicating that households responded to this policy change by reallocating asset ownership.
\end{abstract}

JEL Classification. H24, H31

\footnotetext{
${ }^{+}$H. John Heinz III School of Public Policy and Management, Carnegie Mellon University, 4800 Forbes Avenue, Pittsburgh, PA 15213 E-mail: mstep@cmu.edu

${ }^{*}$ Claremont McKenna College, Dept. of Economics, 500 E. 9th St., Claremont, CA 91711

E-mail: jennifer.ward-batts@mckenna.edu.

Data from the FES is Crown Copyright, was made available by the CSO through the ESRC Data Archive, and has been used by permission. Much of this work on this project was done while the authors were NIA postdoctoral fellows at the University of Michigan's Population Studies Center. We have benefited from comments made during presentations at Carnegie Mellon/University of Pittsburgh, the Institute for Fiscal Studies, the Midwest Economic Association meetings, the Population Association of America meetings, the University of Michigan, and the University of Washington. All errors and interpretations are our own.
} 


\section{Introduction}

There is considerable variation among industrialized countries in how income of married persons is taxed. Tax systems are either individual based (independent taxation) or family based (joint taxation). Systems of joint taxation fall into two categories - income aggregation, in which the sum of family income is taxed as a whole (e.g., the U.S. system), and income splitting, in which half of a couple's income is assigned to each spouse for tax purposes. Countries with income splitting or optional income splitting include Germany, Ireland, and Portugal. Many countries have moved to individual rather than family based income tax, due partly to the distortionary effects of joint taxation on labor supply and human capital investments. Countries with individual-based systems of taxation include Australia, Austria, Denmark, Finland, Greece, Sweden, and the U.K. Joint taxation with income aggregation is relatively uncommon, found in Luxembourg and the U.S., and optional in Spain. ${ }^{1}$

The United Kingdom began taxing incomes of husbands and wives independently in 1990. Previously, all household income was pooled for the purpose of taxation. Following the switch to independent taxation, each spouse is taxed on their own income, both earned and unearned. As with any other tax reform that alters marginal tax rates, separate taxation should affect "real" outcomes, such as labor supply. ${ }^{2}$ However, tax reforms may also provide households opportunities to reduce their tax burdens by simply re-categorizing income without any change in real outcomes. A particularly intriguing aspect of independent taxation in the UK is the potential for intra-household tax avoidance with respect to unearned income. Under the new tax system, each spouse is taxed separately on his or her share of the household's investment income. Households therefore have an incentive to re-allocate shares of investment

\footnotetext{
${ }^{1}$ See OECD (1994) and O’Donoghue and Sutherland (1998) for details of some countries' tax systems.

${ }^{2}$ Although they do not isolate the impact of separate taxation, Blundell, Duncan, and Meghir (1998) use separate taxation along with other income tax changes in the UK to estimate labor supply parameters for married women.
} 
income towards the spouse with the lower marginal tax rate in order to reduce the overall tax burden faced by the household.

Using U.K. Family Expenditure Survey data, we examine the impact of this U.K. tax reform on the intra-household allocation of asset income. While households in which the marginal tax rate differs between spouses will find it advantageous to re-allocate assets, a number of households in which the spousal marginal tax rates are equal face no such incentives. Our identification strategy is a difference-in-differences methodology in which households with no incentive to change their division of assets are used as a control group for those in which the tax reform creates an incentive for income shifting. Furthermore, the tax rate differential between spouses varies across households. We exploit this in order to estimate the responsiveness of intra-household allocation of assets to the magnitude of the tax incentive.

We find a significant reallocation of investment income within households with an incentive to shift assets. In particular, we find an increase in three outcomes: the proportion of wives having any asset income, the fraction of household investment income held by wives, and the fraction of households in which the wife holds all of the asset income. We estimate that a 10 percentage point differential in spouses' marginal tax rates leads to a 2.6-3.1 percentage point increase in the share of investment income allocated to the spouse with the lower marginal tax rate. However, the majority of households do not fully exploit this opportunity to reduce their tax burden.

Although tax avoidance strategies such as those analyzed in this paper are likely more responsive to taxes than "real" outcomes such as consumption and labor supply decisions (Slemrod 1996), only a small body of empirical research has examined avoidance responses to taxes and tax changes. ${ }^{3}$ The tax avoidance literature focuses on two types of avoidance

\footnotetext{
${ }^{3}$ See Slemrod and Yitzhaki (2000) for a survey of the tax avoidance literature.
} 
strategies. The first, timing responses, occur when households shift income to periods when tax rates are low. Burman and Randolph (1994) find that households' capital gains realizations are very responsive to transitory changes in the tax rate while Randolph (1995) finds similar evidence for charitable contributions. Goolsbee (2000) finds large increases in the taxable income of wealthy individuals in 1992, primarily due to the cashing in of stock options, prior to the 1993 increase in the marginal tax rates for the highest earning Americans. The second type of tax avoidance response is through income shifting where households reclassify income in order to reduce their tax burden. The elimination of consumer debt deductibility in the U.S. Tax Reform Act of 1986 led households to reduce their consumer debt but increase their mortgage debt since it remained deductible (Maki 1996). Gordon and Slemrod (1998) find that there has been significant shifting of income between corporate and personal tax bases in the U.S. as the relative tax rates have changed between these two income bases over time. Our examination of investment income shifting between spouses represents a contribution to this latter literature.

The paper is organized as follows: The next section discusses the U.K. tax reforms in more detail. We then briefly discuss the data used for this study as well as the identification strategy we employ. Next we present our empirical results, and the final section concludes.

\section{The Tax Law Reforms}

Prior to April 1990, the family-based U.K. income tax system pooled spousal income for purposes of calculating the family tax bill. ${ }^{4}$ Married men received a Married Man's Allowance (MMA, a tax exemption) which was larger than the Single Person's Allowance (SPA). Unlike in the U.S. where all labor income for a secondary earner is subject to tax (assuming other household income exceeds the household's exemption), U.K. households were eligible for a

\footnotetext{
${ }^{4}$ The tax year begins April 6 and ends April 5.
} 
Wife's Earned Income Allowance (WEIA) that could only be applied to the wife's labor income. ${ }^{5}$ Her labor earnings in excess of the WEIA were taxed jointly with other household income. Any of the WEIA not used against the wife's labor earnings was forfeited (i.e., could not be used against her unearned income or any other household income). In contrast, if the husband's taxable earnings and household unearned income were not large enough to use all of the MMA, the remainder of it could be transferred to the wife and set against her labor earnings. ${ }^{6}$

Independent taxation of spouses began in April 1990, after which each spouse was taxed separately on his or her total (earned and unearned) income, and each now received a Personal Allowance (PA) equal to the SPA. ${ }^{7}$ Since the MMA exceeded the SPA, elimination of the MMA would have increased household tax liability for some couples. To offset this effect, a Married Couple's Allowance (MCA) was introduced and set equal to the difference between the SPA and the old MMA. Like the MMA, the MCA was initially set against the husband's income. Any portion unused by him was transferred to the wife. Beginning in 1993, half or all of the married couple's allowance could be transferred to the wife, even if the husband had sufficient income to use all of it. The MCA gradually decreased in real value over the 1990s, due to erosion from inflation and to a phase-out through limits on the maximum benefit from the allowance, and was eliminated in April 2000. Table 1 contains the tax rates and allowances in the years surrounding the introduction of separate taxation.

In this paper we are interested in the implications of separate taxation for the intrahousehold allocation of asset income. ${ }^{8}$ Prior to this tax reform, the allocation of assets within the

\footnotetext{
${ }^{5}$ The WEIA was always equal to the SPA.

${ }^{6}$ Couples could opt to be taxed separately as single persons, except that all unearned income had to be claimed by the husband. This option, called the "wife's earnings election," resulted in the husband only being eligible for the SPA rather than the larger MMA. Therefore, the wife's earnings election only benefited very high-income dualearner couples.

7 The terms "separate taxation" and "independent taxation" are used interchangeably throughout the paper.

${ }^{8}$ Asset income refers to income from real property and interest and/or dividends from banks, building societies, stocks, and bonds. Capital gains are taxed separately from income, and will not be examined directly in this paper.
} 
household did not matter for income taxation purposes since all investment income was considered to belong to the husband. Following the tax reform, however, households can legally shift assets between spouses and have two options available to them in order to do so. First, they can entirely shift an asset from one spouse to another by giving the asset as a gift. Although there are transactions costs of completely signing over an asset, there are no capital gains taxes incurred when assets are given as a gift between spouses. ${ }^{9}$ The second option involves jointly owned assets. The default split of joint assets for taxation is an even 50-50 split. However, spouses may legally designate an alternate division of joint assets and each spouse is taxed respectively on his or her share of the income generated by that asset. ${ }^{10}$

Since households can reallocate asset income between spouses, the switch to independent taxation gave couples an incentive to transfer assets to the spouse with the lower marginal tax rate in order to reduce the household's tax bill. In many households, this reform created an incentive to transfer a portion or even all of the household's assets to the wife since she faces the lower marginal tax rate. If she works very little or not at all, then the asset income shifted to her may not be taxed at all. Thus, we expect that following independent taxation, the fraction of wives with investment income as well as the wives' share of investment income will increase.

During the first year of independent taxation, the PA could not be used to offset taxes on some types of asset income. ${ }^{11}$ Thus, shifting these assets to a non-working spouse would not have reduced the household's tax burden. This was estimated to have affected five million married women with income less than their PA (H.M. Treasury 1995). Beginning April 1991, all interest income could be set against the PA. We will return to the importance of this secondary change for identifying the impact of separate taxation.

\footnotetext{
${ }^{9}$ If the spouse receiving the gift subsequently disposes of the asset, the capital gains tax is calculated based upon the date and value of the asset when the household initially acquired it.
} 


\section{Empirical Methods}

\section{A. Data}

The Family Expenditure Survey (FES) is an annual survey of U.K. households, a repeated crosssection dataset that has been consistently collected across several decades. ${ }^{12}$ The survey is conducted throughout the year, and either the calendar month or week of the year of the interview is reported. We are therefore able to construct data samples based on the tax year, which runs from April through March. ${ }^{13}$ A random sample of ten thousand households is selected annually, approximately seventy percent of which completes the survey. Face-to-face interviews are conducted with household members to collect information on household and personal expenditures, household demographics, and individual labor supply along with income and its sources. ${ }^{14}$ We use the monthly Retail Price Index to construct an annual price index for each tax year and convert all monetary values to the 1993-94 tax year $£$.

We use data from April 1984 through March 1998. However, to minimize the number of time-varying factors unrelated to the tax law change that may confound our analysis, most of that analysis uses three-year pre- and post-reform periods. April 1987 through March 1990 represents the period before the switch to independent taxation, April 1991 through March 1994 the post-reform period. As discussed above, there was a one-year lag before independent taxation was fully implemented in that some investment income could not be set against an individual's PA until April 1991. We therefore omit the April 1990 to March 1991 transition

\footnotetext{
${ }^{10}$ In order to make a declaration of asset transfer for income tax purposes, including declaring some division of joint ownership other than 50/50, Form 17 must be completed and signed by both spouses and filed with Inland Revenue.

${ }^{11}$ Interest from banks, building societies, and other deposit-takers could not be set against the personal allowance.

${ }^{12}$ The data are collected by the Office of Population Censuses and Surveys Social Survey Division for the Department of Employment and the Central Statistical Office. The data are maintained by the Economic and Social Research Council Data Archive at the University of Essex.

${ }^{13}$ The public use data were available on a calendar year basis through calendar year 1993, at which time they began being distributed on a tax year basis.

${ }^{14}$ Through 1993 the FES was collected using paper and pencil interviews. Beginning in April 1994, the collection of these data switched to using a Computer Aided Personal Interviewing (CAPI) method.
} 
period from our analysis. Finally, since the tax system has some age-based tax allowances, we limit our sample to households in which both spouses are between the ages of 20 and 60 .

\section{B. Identification Strategy}

In order to identify the impact of separate taxation on the intra-household allocation of investment income, we must first identify the group of households for whom independent taxation created an incentive to shift income. Ideally, using a panel dataset spanning the period before and after independent taxation, we could identify households by whether the spouses' marginal tax rates are equal or different after the tax reform. For each of these two groups of households, we could compare their intra-household asset allocation before and after the tax reform. Assuming that no other behaviors (e.g., labor supply) changed due to the tax reform, causing households to shift between the two groups, the impact of the tax reform could be estimated by comparing the relative magnitudes of the changes in asset allocations for the two groups across the two time periods. Unfortunately, no such dataset is available.

The FES provides a repeated cross-section of households before and after the switch to independent taxation. We can easily estimate the marginal tax rates for each spouse in the postreform period. We can then group households in the post-reform period based upon whether the spouses' marginal tax rates are equal or different. The difficulty is in constructing groups of households in the pre-reform period to use as the "before" portion in a difference-in-differences estimator. We cannot apply the tax code in, say, the 1988-89 tax year, since spouses' marginal tax rates would be equal for all households. Rather, we apply the post-reform period tax code to households in the pre-reform period. In particular, we apply the tax code from the 1991-92 tax year (the first year of our post-reform period) to the pre-reform period. ${ }^{15} \mathrm{We}$ are then able to

\footnotetext{
${ }^{15}$ We use the appropriate deflator from the RPI to adjust the nominal tax brackets in 1991-92 tax code when we apply the tax code to the pre-reform years.
} 
estimate marginal tax rates for households in the pre-reform period which in turn allows us to construct the pre-reform treatment and control groups for our difference-in-differences estimator.

In order for the approach of applying the post-reform code to the pre-reform period to work, we must assume that households in the pre-reform period would not have adjusted other dimensions of their behavior, most importantly their labor supply, if they had actually faced the post-reform tax code. ${ }^{16}$ While this assumption is not innocuous, we do not believe it will have a strong impact upon our results. For the majority of married men in our sample, the switch to separate taxation did not affect their marginal tax rate (assuming a secondary earner model). Also, since only two marginal tax rates exist for most of the time period analyzed, small changes in labor supply will not cause these men to switch tax brackets. Further, male labor supply wage and income elasticities are consistently found to be very small (Blundell and MaCurdy 2000). Thus, the assumption that independent taxation had a negligible effect on male labor supply and, more importantly, on the marginal tax rates these men face is likely not far from the truth.

Married women, on the other hand, may have faced larger changes in their marginal tax rates. However, one must remember that prior to independent taxation, married women only faced taxes on labor income above their own allowance (the WEIA), not on the first pound earned. In the absence of large fixed costs of work, married women did not face tax disincentives to participate in the labor force prior to independent taxation, and the switch to independent taxation did not increase their incentive to participate. Even if fixed costs of work were substantial, the switch to independent taxation would have only affected the budget constraint for a small number of women. For women married to men in the $0 \%$ or $25 \%$ marginal tax brackets, the tax reform did not change their marginal tax rate on the first pound earned above their exemption. Women married to men in the $40 \%$ marginal tax bracket saw their 
marginal rate (above the exempt amount) fall from $40 \%$ to $25 \%$ following independent taxation. Thus, there might have been an incentive for a small group of women to enter the labor force following independent taxation - women who both face substantial fixed costs of work and are married to very high income men.

Married women who faced the largest incentives to adjust their labor supply were already in the labor force. However, as with the participation margin, the women who faced changes in their marginal tax rates above the exemption were those married to men in the $40 \%$ tax bracket. Furthermore, estimates of labor supply elasticities for working married women are relatively small (Mroz 1987, Triest 1990). Blundell, Duncan, and Meghir (1998), using U.K. tax reforms including the one examined here, found relatively small labor supply elasticities for married women in the U.K. Overall, any labor supply responses for married women were likely small.

Under the assumption that the labor supply responses by both spouses to separate taxation are small, our strategy for identifying the "before" groups will impart at most a small bias on our estimates of the intra-household shifting of investment income. In an attempt to control for potential biases due to possible labor supply responses that we have outlined above, we also present regression estimates in which we include a variety of demographic controls that are correlated with labor supply behavior. While these regressions will not capture all of the potential biases due to labor supply changes, they will indicate whether the results are robust to minor compositional changes between the different groups. Labor supply responses would arguably be slower than simply shifting asset income, so to further check our results, we estimate the response to separate taxation using only one year before and one year after the tax reform.

The marginal tax rates for each spouse are calculated using his or her own earned and unearned income. However, in engaging in tax avoidance behavior, households should attempt

\footnotetext{
${ }^{16}$ We also created marginal tax rates in pre-reform years by applying that year's tax system to each spouse as if
} 
to equalize the marginal tax rates on their last pound of income. We therefore determine marginal tax rates on all income except investment income. Households in which spouses have equal marginal rates on their own incomes excluding investment income have no incentive to reallocate their investment income following independent taxation. Households where these marginal tax rates differ should be induced to shift investment income between spouses.

\section{C. Estimating the Impact of Separate Taxation on the Allocation of Assets}

We use a difference-in-differences estimator to examine the impact of separate taxation on the intra-household allocation of assets. We identify two treatment groups with opposite incentives. In households in which the husband's marginal tax rate exceeds the wife's, the reform induces a shift of investment income away from husbands toward wives. In households where the wife's marginal rate exceeds the husband's, the switch to separate taxation had the opposite effect. We pool the two treatment groups in our regression analyses, and compare their outcomes to those of a control group in which spouses have equal marginal tax rates. The high-rate-wife group encompasses a very small fraction of our sample, so behavior of high-rate-husband households primarily drives our results.

We focus on a variety of outcomes related to the distribution of investment income within households. We first examine the impact on the fraction of wives with a non-zero share of investment income and the fraction husbands with a non-zero share. If the husband's marginal rate exceeds the wife's, we expect both an increase in the fraction of wives having a non-zero share of investment income, and an increase in the fraction of households in which the husband has no investment income. ${ }^{17}$ The reason for the latter response is that when the husband's

\footnotetext{
independent taxation was in effect. Analysis using these marginal rates is very similar to the results presented here. ${ }^{17}$ We limit our discussion of the expected impacts to the predominant case, where the husband's marginal tax rate exceeds the wife's, for ease of exposition. We expect an exactly opposite set of responses for households in which the wife's marginal tax rate exceeds the husband's.
} 
income excluding investment income greatly exceeds the wife's, there is an incentive to shift all of the investment income to the wife. In addition, we examine the impact of separate taxation on the share of investment income held by wives. In households where the husband's rate is higher, independent taxation induced an increase in the share of investment income held by wives. Finally, we present evidence of the tax reform's impact on the distribution of the investment income shares held by wives rather than focusing on only the shift in the mean share.

We first examine changes for the treatment group, in which one spouse has a higher marginal rate than the other, relative to the control group. ${ }^{18}$ We then exploit an additional source of variation created by multiple tax bands: the magnitude of the difference in marginal rates varies across households. Larger differences in the spouses' marginal rates give a stronger incentive for households to shift investment income between spouses. We therefore also employ a modified difference-in-differences methodology that incorporates the magnitude of the spouses' marginal tax rate differences within households. ${ }^{19}$

The top and bottom panels of Table 2 present summary statistics for households in the pre- and post-reform samples respectively. Each panel divides households into three groups: the control group consisting of households where spouses have equal marginal tax rates, households where the husband's marginal rate is higher, and households where the wife's marginal rate is higher. The characteristics of the households in each group across the two time periods are very similar. $^{20}$ The households in the post-reform period are slightly older and more educated although these differences exist across all three groups and are therefore not indicative of

\footnotetext{
${ }^{18} \mathrm{We}$ have also conducted analysis treating high-marginal-rate-husband households as a separate treatment group than high-marginal-rate-wife households. Results are very similar to those presented here, except that there is less precision in the latter group. These results are available from the authors.

${ }^{19}$ The 1992 tax year introduction of the lower rate of $20 \%$ on the initial amount of income creates a minor difficulty for our construction of the tax rate difference groups. Also, the basic rate fell to $24 \%$ in 1996 and 23\% in 1997. For consistency throughout our analysis, we treat anyone with a tax rate between $20 \%$ and $25 \%$, inclusive, as having a tax rate of $25 \%$.
} 
households shifting between groups. More interesting is the relative stability of hours worked within each group across the two time periods. ${ }^{21}$ While these summary statistics are not definitive, they do suggest that the composition of the groups was relatively stable over time.

\section{Empirical Evidence of the Impact of Separate Taxation on Asset Allocation}

\section{A. Long-Run Trends in Intra-Household Asset Allocations}

We first present evidence that the shift in investment income occurs when independent taxation is implemented. If there was a long-term trend towards wives possessing a larger fraction of household investment income that differed between the treatment and control groups, then our difference-in-differences strategy may lead us to infer that separate taxation had a causal effect when it did not. However, sharp movements in the time series of measures of intra-household asset allocation suggest a causal interpretation of our difference-in-differences estimator.

Figure 1 shows the fraction of households in our sample with investment income, and the fraction of households in which the wife has investment income for tax years 1984-85 through 1997-98. Over this period, the fraction of households with investment income increases slightly and then declines. ${ }^{22}$ The time series for the fraction of wives with some investment income parallels the fraction of households with investment income. There are no dramatic shifts in either series that would suggest the composition of the group of households with investment income changed over the period, and no dramatic shift in the fraction of wives with investment income is apparent. Although Figure 1 shows a decline in the aggregate fraction of households with investment income, this decline did not differ between our treatment and control groups. ${ }^{23}$

\footnotetext{
${ }^{20}$ Restricting the households in Table 2 to only those with investment income also shows that the characteristics of each of the groups remain stable over time.

${ }^{21}$ The change in hours is larger for third group, but this group is small and therefore prone to noise.

22 Banks, Dilnot, and Low (1995) find similar evidence of this decline using a separate data set.

${ }^{23}$ Graphing the fraction of households with some investment income by tax rate difference groups (those where spouses have the same marginal rate versus those where the husband's rate is higher) reveals that the fraction of
} 
Figure 2 presents time-series plots for the share of household investment income held by the wife. Prior to separate taxation, wives with lower marginal tax rates than their husbands consistently held a smaller share of investment income than wives with marginal tax rates equal to that of their husbands. ${ }^{24}$ Beginning in 1991, when separate taxation is fully implemented, there is an increase in the fraction of investment income held by wives in households with incentives to shift income following the tax reform. Although the reform began in 1990, the aforementioned delay in full implementation of the tax reform (spouses in the zero marginal tax bracket could not claim investment income until 1991) may have delayed the response for a number of households. However, this delay lends credibility to our identification strategy. Since we assign pre-reform households to the treatment and control groups by applying the post-reform tax code, an incorrect classification during this era may lead to the erroneous appearance of shifting when none actually occurred. Since 1990 is in the post-reform period (but before the law was fully implemented), households in that year are assigned based upon the current year's tax law. The relative continuity of the two series in Figure 2 between 1989 and 1990 suggests that our assignment method is not responsible for shifting of investment income toward wives. These time-series plots, as well as others we examined, are suggestive of a causal interpretation for the impact of separate taxation on the intra-household allocation of investment income.

\section{B. Distributional Effects of Independent Taxation}

Another graphical approach is to directly examine the distributions of investment income before and after the tax reform. Here, we limit our sample to the three-year pre-reform (tax years 19871989) and post-reform (tax years 1991-1993) periods. Within each tax rate difference group (equal marginal rates, husband's rate higher, and wife's rate higher), we examine how

households with investment income is similar for these two groups. Time-series changes in the fraction of households with investment income are in the same direction for both groups. (Graph available from the authors.) 
independent taxation affected the distribution of the wife's share of investment income among those households with investment income.

Figure 3 (a) presents the cumulative distribution functions in the pre- and post-reform periods for the wife's share of investment income among households in which the spouses' marginal rates are equal. ${ }^{25}$ Since independent taxation did not give these households an incentive to shift investment income, the CDF should not change when the reform is implemented. The two CDFs are nearly identical. We test for equality between them using a Kolmogorov-Smirnov (KS) test. The KS test statistic is 0.025 with a p-value of 0.242 . Confirming our visual evidence, we cannot reject the hypothesis that the CDF did not change following independent taxation for households in which the spouses' marginal rates are equal.

The CDFs for households in which the husband's marginal tax rate is higher are shown in Figure 3 (b). Since the tax reform encouraged these households to shift investment income towards wives, the CDF for the post-reform period should exhibit first-order stochastic dominance over the pre-reform CDF. The visual evidence is consistent with this hypothesis. The KS test statistic for equality of these CDFs is 0.146 with a p-value less than 0.01 . Furthermore, the test statistic for first order stochastic dominance is also 0.146 with a p-value less than 0.01. Thus, independent taxation shifted the distribution of assets in the expected direction for these households.

For households in which the wife's marginal rate is higher, the pre-reform CDF should stochastically dominate the post-reform CDF. In Figure 3 (c), it appears that this hypothesis is true for values of the wife's fraction of investment income exceeding 50\%. However, the left side of the distribution exhibits exactly the opposite behavior. The KS test statistic for the

\footnotetext{
${ }^{24}$ Households in which the wife has the higher marginal rate exhibit a lot of noise and are excluded from Figure 2.

${ }^{25}$ Figures 3 (a) and (b) are derived by plotting the CDF at every .025 along the horizontal axis. Due to the small sample sizes available, Figure 3 (c) is derived by plotting the CDF at every 0.05 along the horizontal axis.
} 
equality of these CDFs is 0.067 with a p-value of 0.654 . It is not surprising that we are unable to reject equality of the two distributions for these households given the small group size.

These CDFs show that the switch to independent taxation had the hypothesized effects on the intra-household allocation of investment income. The CDFs shifted in the hypothesized direction for our largest treatment group, where the husband has the higher tax rate. Equally as important, the CDFs remain constant over time for the control group, further suggesting that the switch to independent taxation had a causal effect on intra-household investment income.

\section{C. Difference-in-differences Estimates}

We estimate difference-in-differences regression models, both with and without demographic controls, in order to ascertain the robustness of the tax-reform estimates. ${ }^{26}$ Our measure of the incentive to shift investment income between the spouses is the marginal tax rate difference, which is defined as the husband's rate less the wife's rate, and is interacted with the post-reform dummy variable. ${ }^{27}$ The probability the wife (husband) has some investment income and the share of investment income claimed by the wife should be increasing (decreasing) in this variable. This strategy allows us to estimate how the magnitude of the spouses' tax rate differential affects the magnitude of investment income shifting between spouses. ${ }^{28}$

The results from estimating these models are presented in Table 3 for all three outcomes: the fraction of wives with asset income, the share of household investment income held by

\footnotetext{
${ }^{26}$ Regressions with demographic controls include a quadratic in the head's age; a quadratic in the wife's age; number of children; number of children under 5; the wife's and husband's years of education; year effects for 1988, 1989, 1992, and 1993; and regional dummies for Greater London, Wales, Scotland, and Ireland. Year effects are intended to capture trends that are unrelated to the tax reform.

${ }^{27}$ This variable can be either positive or negative depending upon which spouse has a higher marginal tax rate. ${ }^{28} \mathrm{We}$ also estimated "pure" difference-in-differences models (without the magnitude of the tax differential). We interact the post-reform variable with a variable that takes on the values $(-1,0,+1)$ depending upon the hypothesized direction of the asset shift. These results are significant and of the expected sign (available from the authors).
} 
wives, and the fraction of wives holding all of the asset income. ${ }^{29}$ Models (1), (3), and (5) show that the tax reform had the hypothesized effect for all three outcomes. That the "post-reform" coefficient is not statistically different from zero indicates that there was no change in these outcomes for the control group, confirming our findings from Figure 3 (a). Models (2), (4), and (6) in Table 3 show that our analysis is robust to the inclusion of demographic characteristics. ${ }^{30}$

We can estimate how much an increase in the tax rate differential between spouses causes the household to shift investment income using the results in Table 3. In column 6, the results indicate that a 10 percentage point increase in the tax rate differential between the two spouses leads to a 2.6 percentage point increase in the share of investment income held by the wife. In results not shown here, a comparable estimate in which we do not pool the treatment groups indicates a 3.1 percentage point increase for households in which the husband's marginal rate exceeds the wife's rate. ${ }^{31}$ At the maximum tax rate difference of 40 percentage points, our results imply that between 10 and 12 percent of household investment income would be shifted to the spouse with the lower marginal rate.

\section{D. Robustness Checks}

While the results presented thus far provide fairly convincing evidence that the switch to independent taxation caused a shift in investment income between spouses, it is possible that

\footnotetext{
${ }^{29} \mathrm{We}$ report results from linear models. Using non-linear limited dependent variable models for each regression model in Table 3 does not change results. Standard errors for regression results presented here use White's method to adjust for heteroskedasticity. We also used two other methods to check robustness of these results. First, we divided households into nine groups based on marginal rates of the two spouses, and allowed error terms for households within each of these groups to be correlated with one another - within tax years as well as across tax years - in order to calculate the standard errors. Our inferences are not qualitatively affected by using these standard errors. Second, we limited the sample to the last year in the pre-reform period (1989) and the first year in the post-reform period (1991) since the primary identifying variation is due to the change in 1990. The resulting inferences are generally the same as those reported, although some point estimates differ slightly. These results (available from the authors) suggest our inferences are robust.

${ }^{30}$ Although the coefficient for the wife receiving any investment income becomes insignificant when demographics are included, the point estimate is well within the confidence interval for the estimate excluding demographics.

${ }^{31}$ Due to the presence of households in which the wife's fraction of investment is zero or one, we cannot use a log dependent variable to more easily estimate elasticities of income shifting.
} 
other factors are influencing our results. One possibility is that households shifted assets to take advantage of another opportunity to lower their tax burden through the use of capital gains exemptions. Prior to independent taxation, a household received only one annual exemption to set against capital gains. Independent taxation led to each spouse having his or her own capital gains exemption. This exemption is rather sizable; it was $£ 5,000$ in tax year 1990 while the personal exemption for income in that year was $£ 3,005$. On the one hand, such a large exemption may lead households to shift investment between spouses in order to increase the size of the gain exempt from taxation. On the other hand, given such a large exemption, households may not need to shift assets since one exemption alone may cover their capital gains for a given year. However, some households may be shifting investment income to take advantage of the capital gains exemption rather than the lower marginal income tax rate.

To investigate this, we divide investment income into three components. The first, savings income (bank deposits), is only taxable as income and does not generate a capital gain. The second, stocks and bonds, may generate interest and dividend income, and may also generate capital gains when sold. Finally, real property income is subject to income tax, while sale of property may generate a capital gain.

Table 4 examines the impact of independent taxation on the wife's share of each of these components. The first two columns present results for savings income. ${ }^{32}$ These are almost identical to those for the wife's share of income in Table 3. The results in Table 4 for income from stocks and bonds in columns (3) and (4), and from property in columns (5) and (6), are all of the expected sign, but are statistically insignificant. One reason for the lack of significance is

\footnotetext{
${ }^{32}$ Some types of bank deposits (TESSAs and the first 70 pounds of interest income from ordinary accounts with the National Savings Bank) are not subject to income tax. Results from regressions in which these types of deposits are removed are nearly identical to those presented here.
} 
the reduction in the sample size for these regressions. ${ }^{33}$ Even so, the magnitude of the shift for these assets is far less than the results we find for savings income. Thus, while households may be shifting some of their assets to take advantage of the capital gains exemptions, our results are primarily driven by savings income that is not subject to capital gains tax.

Another concern is the relationship between the household's marginal tax rate differential and the amount of the household's investment income. If households with the largest gains from shifting investment income are also those that have the highest levels, part of the shifting that we attribute to the tax rate differential may be due to the fact that households with higher levels of income are more likely to shift it. To explore this, we divided households into investment income quartiles and re-estimated the outcomes in Table 3, allowing for different impacts for each quartile. ${ }^{34}$ The results (not shown here) indicate that the increase in wives having investment income, and the decrease in husbands having investment income, are most prevalent in the lower end of the investment income distribution. In general, these results suggest that the response to the tax rate differential varies across the investment income distribution, but that the differences are not exclusively larger for households with more investment income.

As a final robustness check, we examined the fraction of households reporting a 50-50 split of investment income. ${ }^{35}$ In the pre-reform period, the wife's fraction of investment income was, on average, less than 50 percent. Since the default split of jointly held assets following independent taxation is 50-50, the increase in the wife's share of investment income may be simply due to an increase in households reporting the default split of these assets. However, Figure 3 shows that the percentage of households reporting a 50-50 split remained constant in the control groups while it appears to fall in the two treatment groups. Furthermore, in results not

\footnotetext{
${ }^{33} 25 \%$ of households in the sample have income from stocks or bonds; $72 \%$ have savings income.

${ }^{34} \mathrm{We}$ also estimated models in which we interacted the tax rate differential with the level of investment income. The results of these models provide similar qualitative results to those found in Table 4.
} 
shown here, we find that the fraction of households reporting a 50-50 split of investment income significantly decreases for high-marginal-rate-husband households relative to the control group while there is no relative change for households in which the wife has the higher marginal tax rate. Therefore, this mechanical change is not responsible for the results that we find.

\section{E. Are Households “Optimally” Re-Allocating Assets?}

Although we find that households responded to the incentives to shift investment income, another question one might ask is whether households responded optimally. Of course, the definition of optimal depends upon the model of household decision-making (i.e., unitary vs. collective) and institutional factors (e.g., divorce laws) affecting the household's decision processes. Here, we define the optimal allocation of investment income as that which minimizes the household's tax burden. While this may not be the true optimum, this approach answers a natural baseline question concerning the impact of the tax rate differential on the household's investment income allocation.

First, we determine the minimum share of investment income that should be allocated to the spouse with the lower marginal rate for optimality, i.e., for the spouses to just equalize their (final pound) marginal tax rates. This allows us to estimate the optimal amount of re-allocation we would expect to see. In addition, we are interested in how a household's own efforts can move it closer to its optimal allocation. If tax brackets are not perfectly indexed over time, then households could move closer to (or further away from) the optimum with no behavioral change.

Among households in which the husband's marginal rate exceeds the wife's, over $90 \%$ would need to allocate all of their investment income to the wife in order to take full advantage of the tax incentive, and the minimum share that would need to be shifted in the pre- and post-

\footnotetext{
${ }^{35}$ To account for measurement error, we also estimated models where we examined the fraction of households reporting the wife's share of investment income as being between $45 \%$ and $55 \%$. The results were very similar.
} 
reform periods is almost identical. Although a significant number of these households moved closer to the optimal allocation of assets, only $18 \%$ optimally allocated their assets. In households where the wife's marginal rate exceeds the husband's, a large majority would optimize by shifting all of their investment income to the husband. Among this group, only $30 \%$ chose the correct allocation. The failure of so many households to choose the "optimal" allocation may be due to spouses optimizing along dimensions other than total household tax burden. Understanding why households do not choose to minimize household tax liability is an interesting area for further research, but is beyond the scope of this paper.

\section{Conclusion}

The switch to separate taxation of spouses in the UK created an incentive for married couples to shift investment assets to the spouse with the lower marginal tax rate, typically the wife. By exploiting this form of tax avoidance, households are able to reduce their total tax burden. Our analysis of the impact of separate taxation on the intra-household allocation of investment income provides strong evidence that households did indeed take advantage of this opportunity for tax avoidance through income shifting. In households with an incentive to shift investment income, we find an increase in the fraction of lower rate spouses as well as a reduction in the fraction of higher rate spouses with investment income. In addition, we find an overall increase in the share of investment income held by the spouse with the lower marginal rate.

We estimate that a 10 percentage point increase in the marginal tax rate differential between spouses leads to a 2.6-3.1 percentage point increase in the share of investment income shifted to the spouse with the lower marginal tax rate. Our results are robust to a variety of influences that may possibly confound our analysis. However, even though many households take advantage of the income shifting incentives due to separate taxation, an overwhelming majority of households do not fully exploit their ability to reduce their tax burden. 


\section{Bibliography}

Banks, James, Andrew Dilnot, and Hamish Low. "Patterns of financial wealth-holding in the United Kingdom," in New Inequalities: An Inquiry Into the Link Between Income and Wealth. ed. J. Hills. Cambridge: Cambridge University Press.

Blundell, Richard, Alan Duncan, and Costas Meghir. 1998. "Estimating Labor Supply Responses Using Tax Reforms," Econometrica, 44(4):827-861.

Blundell, Richard and Thomas E. MaCurdy 2000. "Labor Supply: A Review of Alternative Approaches," in Handbook of Labor Economics, Volume 3, eds. Orley Ashenfelter and David Card. Amsterdam: Elsevier Science Publishers BV.

Burman, Leonard E. and William C. Randolph 1994. "Measuring Permanent Responses to Capital-Gains Tax Changes in Panel Data," The American Economic Review, 84(4): 794809.

Department of Health and Social Security. Social Security Statistics, London: H.M.S.O.; 1984.

Goolsbee, Austan. 2000. "What Happens When You Tax the Rich? Evidence from Executive Compensation," Journal of Political Economy, 108(2): 352-378.

Gordon, Roger and Joel Slemrod. "Are 'Real' Responses to Taxes Simply Income Shifting Between Corporate and Personal Tax Bases?” NBER Working Paper 6576, 1998.

H.M. Treasury. 1995. Tax Benefit Reference Manual, 1995/96 Edition. London: H.M.S.O.

Mroz, Thomas A. 1987. "The Sensitivity of an Empirical Model of Married Women's Hours of Work to Economic and Statistical Assumptions," Econometrica, 55(4): 765-799.

O'Donoghue, Cathal and Holly Sutherland. 1998. "Accounting for the Family: The Treatment of Marriage and Children in European income Tax Systems," Innocenti Occasional Papers, Economic and Social Policy Series, No. 65.

OECD. 1994. Taxation and Household Saving: Country Surveys. OECD: Paris.

Randolph, William C. 1995. "Dynamic Income, Progressive Taxes, and the Timing of Charitable Contributions." Journal of Political Economy, 103(4): 709-738.

Slemrod, Joel. 1996. "Income Creation or Income Shifting? Behavioral Responses to the Tax Reform Act of 1986," The American Economic Review, 85(2): 175-180.

Slemrod, Joel and Shlomo Yitzhaki. 2000. "Tax Avoidance, Evasion, and Administration." NBER Working Paper 7473.

Triest, Robert K. 1990. "The Effect of Income Taxation on Labor Supply in the United States," Journal of Human Resources, 25(3): 491-516. 
Figure 1 - Percentage of Households with Investment Income and Percentage of Households Where the Wife has Investment Income

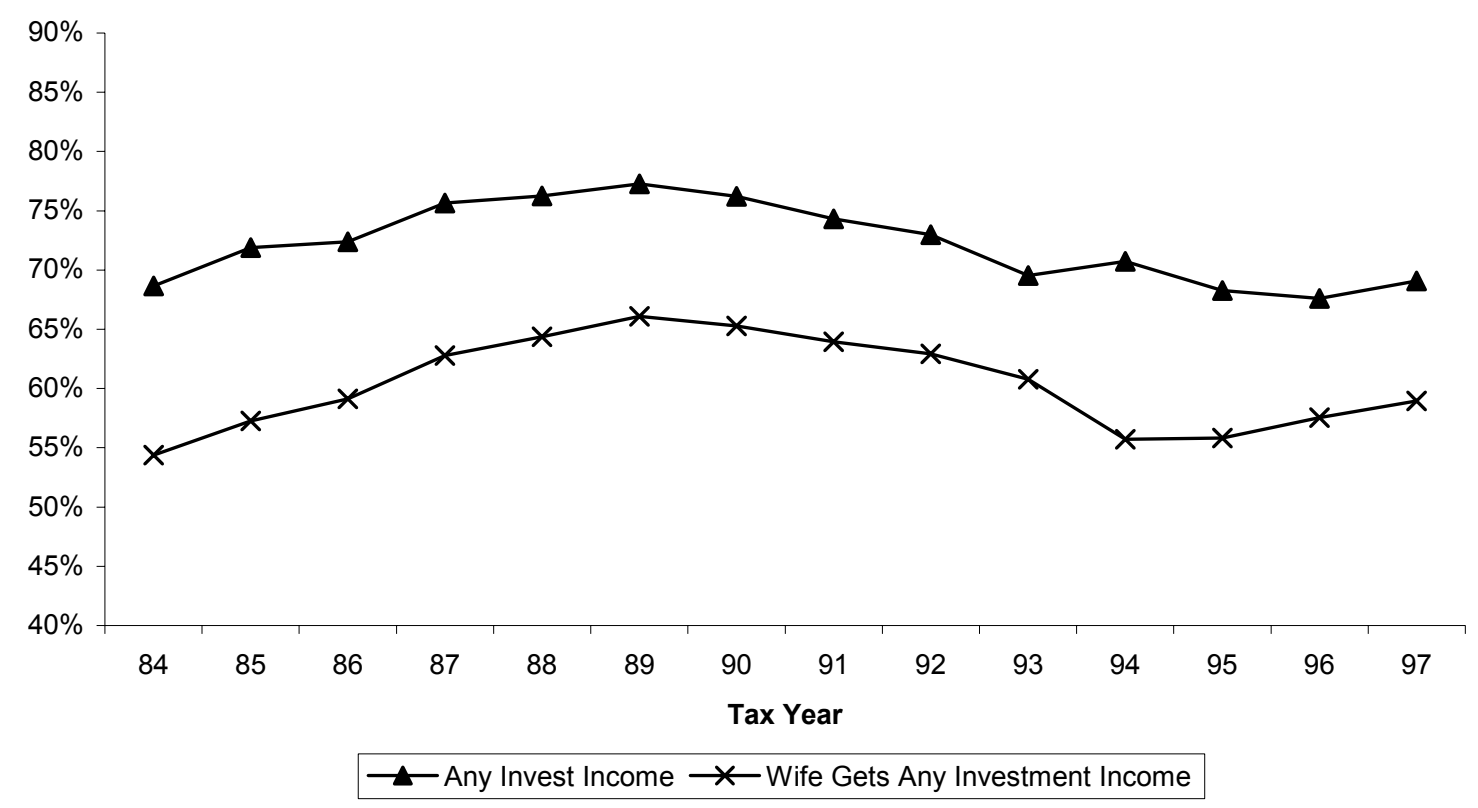

Figure 2 - Wives' Fraction of Investment Income

By Tax Rate Difference Group

Among Households With Investment Income

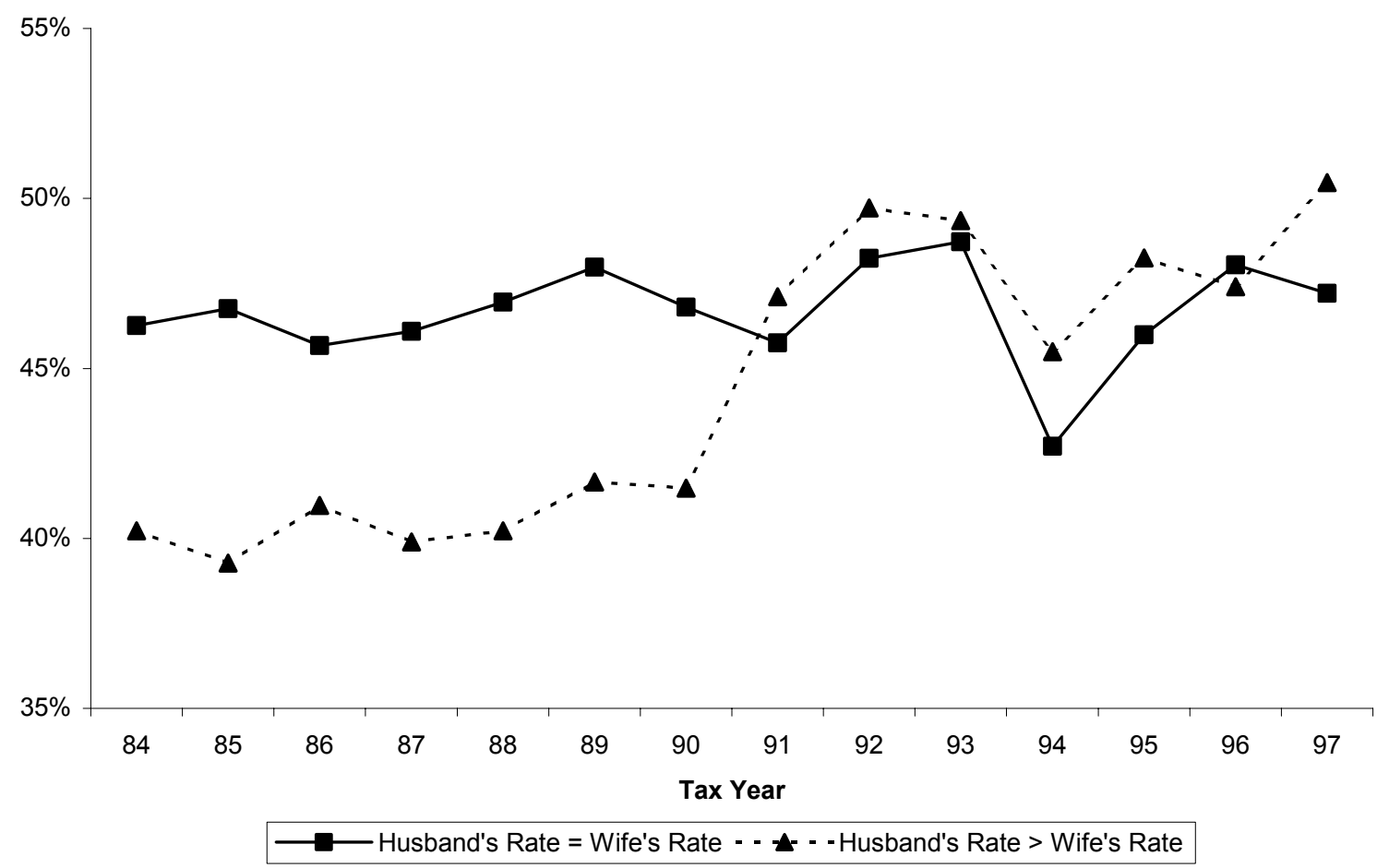


Figure 3 - Cumulative Distribution Functions of Wife's Share of Investment Income Pre-Reform vs. Post-Reform

(a) Husband's Rate = Wife's Rate

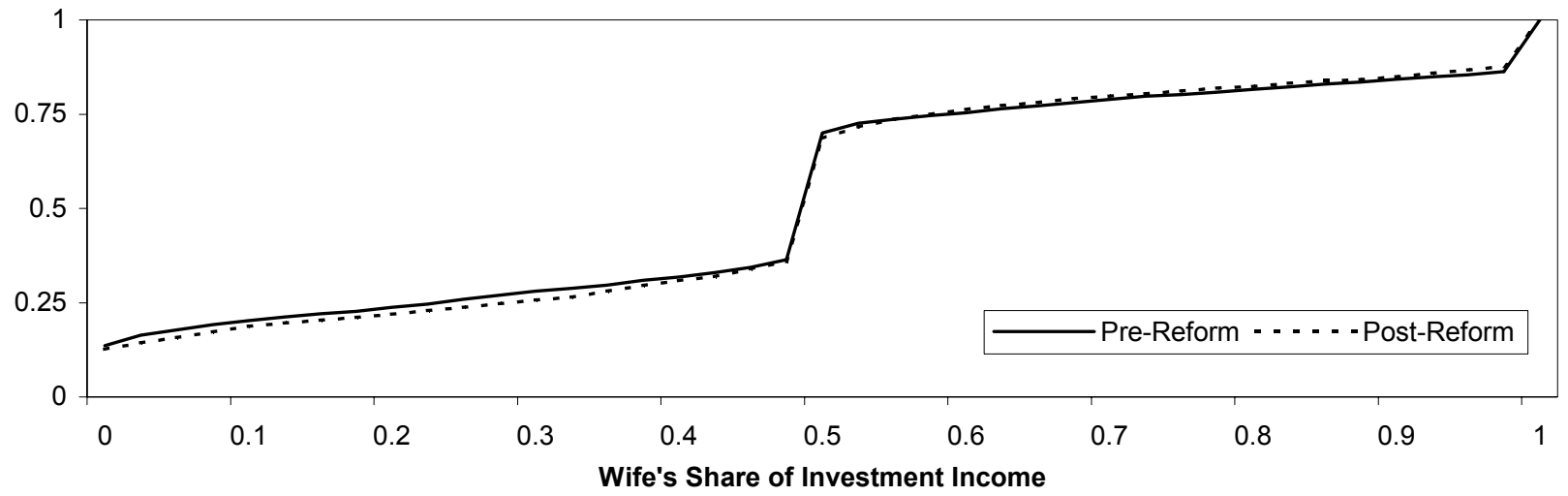

(b) Husband's Rate > Wife's Rate

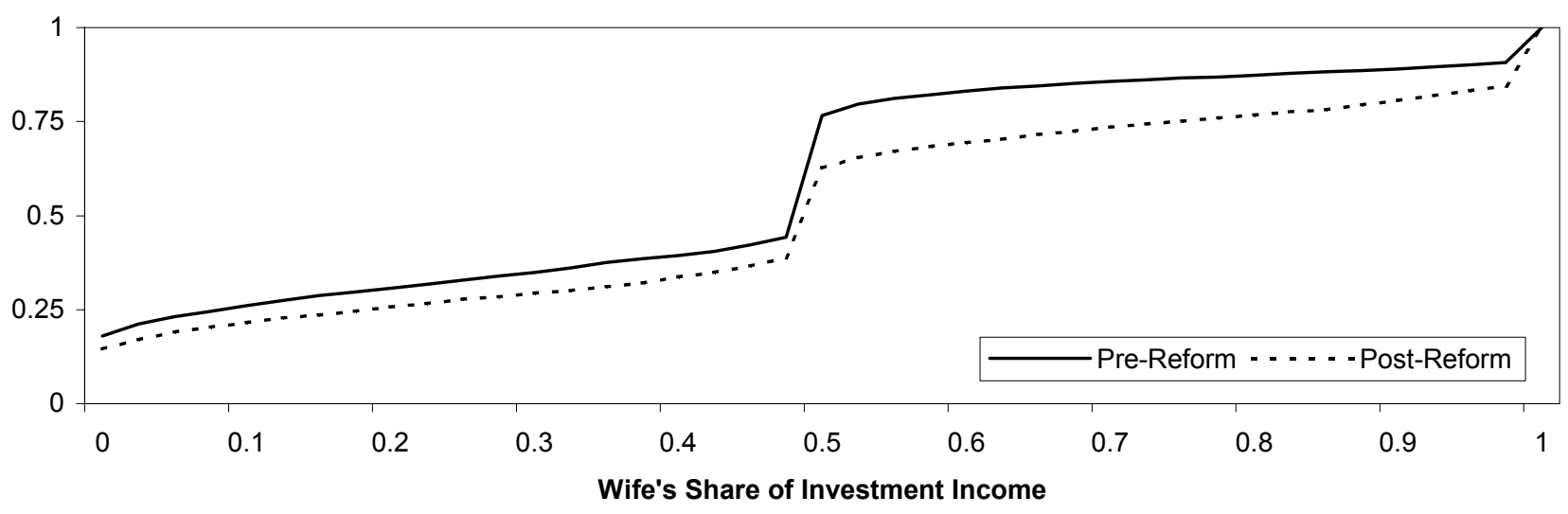

(c) Hus band's Rate < Wife's Rate

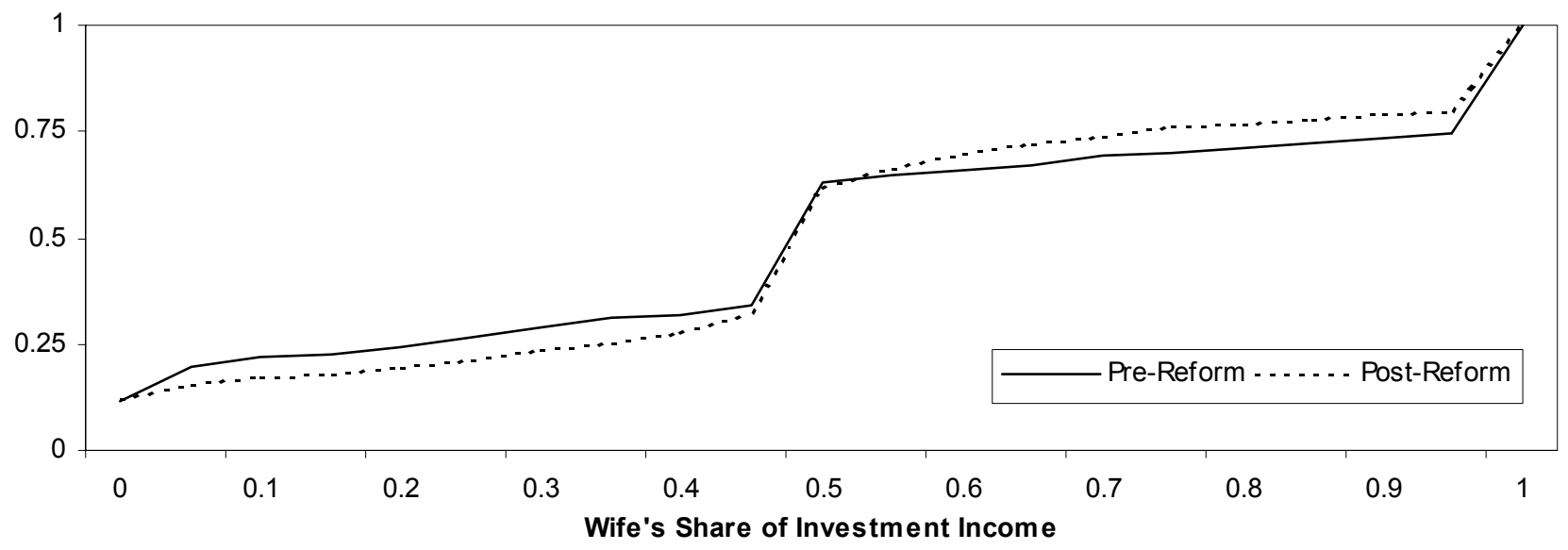


Table 1 United Kingdom Tax Rates and Allowances, 1987-1993 Tax Years

\begin{tabular}{|c|c|c|c|c|c|c|}
\hline $\begin{array}{l}\text { Tax } \\
\text { Year }\end{array}$ & $\begin{array}{l}\text { Lower Rate } \\
\text { (Taxable } \\
\text { Income) }\end{array}$ & $\begin{array}{l}\text { Basic Rate } \\
\text { (Taxable } \\
\text { Income) }\end{array}$ & $\begin{array}{l}\text { Higher } \\
\text { Rate(s) }\end{array}$ & $\begin{array}{c}\text { Single Person's/ } \\
\text { Personal } \\
\text { Allowance }\end{array}$ & $\begin{array}{c}\text { Married } \\
\text { Man's } \\
\text { Allowance }\end{array}$ & $\begin{array}{c}\text { Married } \\
\text { Couple's } \\
\text { Allowance }\end{array}$ \\
\hline $1987-88$ & & $\begin{array}{c}27 \% \\
(1-17,900)\end{array}$ & $\begin{array}{c}40,45,50 \\
55,60\end{array}$ & 2,425 & 3,796 & \\
\hline 1988-89 & & $\begin{array}{c}25 \% \\
(1-19,300)\end{array}$ & 40 & 2,605 & 4,095 & \\
\hline $1989-90$ & & $\begin{array}{c}25 \% \\
(1-20,700)\end{array}$ & 40 & 2,785 & 4,375 & \\
\hline $1990-91$ & & $\begin{array}{c}25 \% \\
(1-20,700)\end{array}$ & 40 & 3,005 & & 1,720 \\
\hline 1991-92 & & $\begin{array}{c}25 \% \\
(1-23,700)\end{array}$ & 40 & 3,295 & & 1,720 \\
\hline $1992-93$ & $\begin{array}{c}20 \% \\
(1-2,000)\end{array}$ & $\begin{array}{c}25 \% \\
(2,001-23,700)\end{array}$ & 40 & 3,445 & & 1,720 \\
\hline 1993-94 & $\begin{array}{c}20 \% \\
(1-2,500) \\
\end{array}$ & $\begin{array}{c}25 \% \\
(2,501-23,700)\end{array}$ & 40 & 3,445 & & 1,720 \\
\hline
\end{tabular}

Table 2 - Summary Statistics, All Households

Pre-Reform (Tax Years 1987-88 to 1989-90)

\begin{tabular}{|c|c|c|c|c|c|c|}
\hline \multirow[b]{2}{*}{ Husband's Age } & \multicolumn{2}{|c|}{$\begin{array}{c}\text { Husband's Rate = } \\
\text { Wife's Rate } \\
(\mathrm{N}=4694)\end{array}$} & \multicolumn{2}{|c|}{$\begin{array}{c}\text { Husband's Rate > } \\
\text { Wife's Rate } \\
(\mathrm{N}=4630)\end{array}$} & \multicolumn{2}{|c|}{$\begin{array}{c}\text { Husband's Rate }< \\
\text { Wife's Rate } \\
(\mathrm{N}=280)\end{array}$} \\
\hline & 41.2 & $(0.15)$ & 40.5 & $(0.14)$ & 43.9 & $(0.64)$ \\
\hline Wife's Age & 38.7 & $(0.15)$ & 38.0 & $(0.14)$ & 41.7 & $(0.62)$ \\
\hline Husband's Years of Education & 10.2 & $(0.03)$ & 10.5 & $(0.04)$ & 10.4 & $(0.18)$ \\
\hline Wife's Years of Education & 10.4 & $(0.03)$ & 10.2 & $(0.03)$ & 10.8 & $(0.17)$ \\
\hline Husband's Hours of Work & 29.5 & $(0.28)$ & 33.4 & $(0.26)$ & 7.2 & $(1.03)$ \\
\hline Wife's Hours of Work & 25.4 & $(0.22)$ & 6.3 & $(0.15)$ & 26.7 & $(0.93)$ \\
\hline \multicolumn{7}{|c|}{ Post-Reform (Tax Years 1991-92 to 1993-94) } \\
\hline & \multicolumn{2}{|c|}{$\begin{array}{c}\text { Husband's Rate }= \\
\text { Wife's Rate } \\
(\mathrm{N}=4266) \\
\end{array}$} & \multicolumn{2}{|c|}{$\begin{array}{c}\text { Husband's Rate }> \\
\text { Wife's Rate } \\
(\mathrm{N}=3706) \\
\end{array}$} & \multicolumn{2}{|c|}{$\begin{array}{c}\text { Husband's Rate }< \\
\text { Wife's Rate } \\
(\mathrm{N}=359) \\
\end{array}$} \\
\hline Husband's Age & 42.0 & $(0.15)$ & 41.3 & $(0.16)$ & 44.2 & $(0.53)$ \\
\hline Wife's Age & 39.6 & $(0.15)$ & 39.3 & $(0.16)$ & 41.7 & $(0.49)$ \\
\hline Husband's Years of Education & 10.4 & $(0.04)$ & 10.9 & $(0.05)$ & 10.4 & $(0.14)$ \\
\hline Wife's Years of Education & 10.6 & $(0.03)$ & 10.6 & $(0.04)$ & 10.9 & $(0.13)$ \\
\hline Husband's Hours of Work & 28.5 & $(0.30)$ & 33.5 & $(0.31)$ & 5.7 & $(0.78)$ \\
\hline Wife's Hours of Work & 24.4 & $(0.23)$ & 6.6 & $(0.17)$ & 29.0 & $(0.77)$ \\
\hline
\end{tabular}

Note: Sub-sample means, standard errors in parentheses. 


\section{Table 3}

The Impact of Separate Taxation on the Allocation of Investment Income Interactions with the Magnitude of the Tax Rate Differential

Households with Investment Income

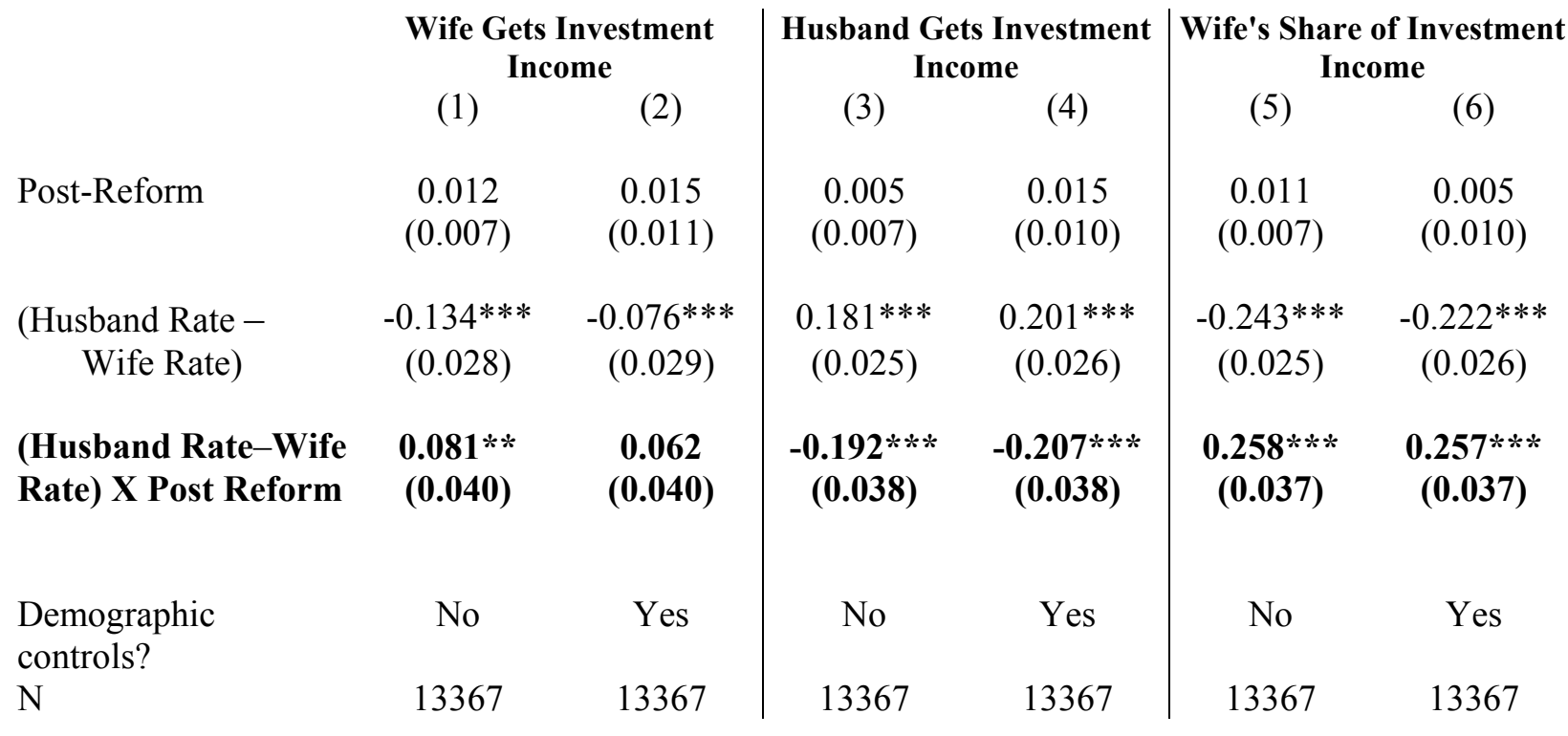

Table 4

The Impact of Separate Taxation on the Allocation of Investment Income Interactions with the Magnitude of the Tax Rate Differential

By Investment Income Category

Households with Investment Income

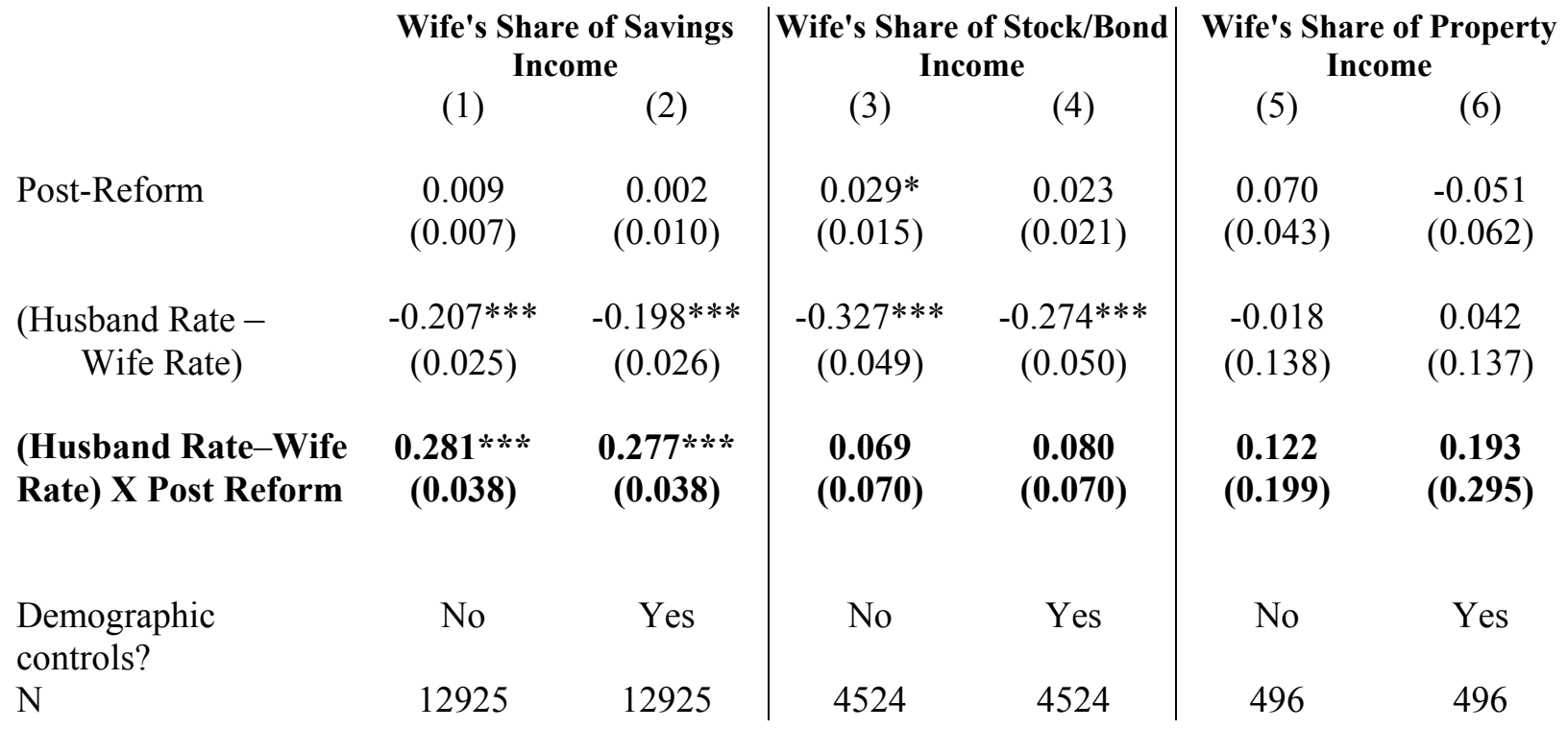

***, **, * $\mathrm{p} \leq .01, .05, .10$ respectively (White standard errors in parentheses) using two-tailed t-tests

Demographic controls include a quadratic in the husband's age; a quadratic in the wife's age; number of children; number of children under 5; the wife's and husband's years of education; year effects for 1988, 1989, 1992, and 1993; and regional dummies for Greater London, Wales, Scotland, and Northern Ireland 